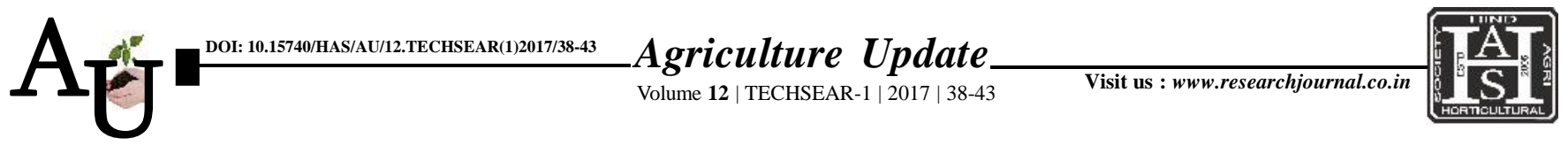

ם ISSN-0976-6847

\title{
Research Article: A ricardian analysis of the impact of climate change and adaptation strategies of millet crops in Tamil Nadu
}

\section{G. PARTHASARATHI AND R. BALASUBRAMANIAN}

Article Chronicle : Received :

05.07.2017;

Accepted :

22.07.2017

KEY Words:

Climate change, Millets, Ricardian model, Multinomial Logit (MNL)

Author for correspondence :

G. PARTHASARATHI

S. Thangapazham Agricultural College, VASUDEVANALLUR (T.N.) INDIA

Email:sarathykillikulam@ gmail.com

See end of the article for authors' affiliations
SUMMARY : This study was conducted in various districts of Tamil Nadu examined the climate change impacts of major millet crops. The Ricardian model is used analyze the climate change impacts in millet crops. The Multinomial logit model is used to analyze the determinants of farmer's choice of adaptation strategies. The results of multinomial logit analysis show that increase rainfall significantly reduced the likelihood of using certain adaptation strategies, but increased the probability of changing the sowing dates to adapt to the climate change.

How to cite this article : Parthasarathi, G. and Balasubramanian, R. (2017). A ricardian analysis of the impact of climate change and adaptation strategies of millet crops in Tamil Nadu. Agric. Update, 12(TECHSEAR-1) : 3843; DOI: 10.15740/HAS/AU/12.TECHSEAR(1)2017/38-43. 